\title{
Performance of Five Turfgrasses under Linear Gradient Irrigation
}

\author{
Y.L. Qian \\ Department of Horticulture and Landscape Architecture, Colorado State \\ University, Fort Collins, CO 80523-1173
}

\author{
M.C. Engelke \\ Texas A\&M Research and Extension Center, Texas A\&M University System, \\ 17360 Coit Road, Dallas, TX 75252-6599
}

Additional index words. drought resistance, water requirements, Buchloe dactyloides, Cynodon dactylon, Festuca arundinacea, Stenotaphrum secundatum, Zoysia japonica, fungal infection.

\begin{abstract}
Determining the appropriate level of irrigation for turfgrasses is vital to the health of the turfgrass and the conservation of water. The linear gradient irrigation system (LGIS) allows long-term assessment of turf performance under continuous irrigation gradients from excess to no irrigation. The objectives of this study were to: 1) evaluate the minimum irrigation requirements and relative drought resistance of 'Rebel II' tall fescue (Festuca arundinacea Schreb.), 'Meyer' zoysiagrass (Zoysia japonica Steud.), 'Tifway' bermudagrass [Cynodon dactylon (L.) Pers.], 'Prairie' buffalograss [Buchloe dactyloides (Nutt.) Engelm], and 'Nortam' St. Augustinegrass [Stenotaphrum secundatum (Walt.) Kuntze]; and 2) evaluate the long-term effects of irrigation levels on turf persistence, weed invasion, and disease incidence for the five selected turfgrasses under field conditions. Turf was sodded under LGIS with an irrigation gradient ranging from $120 \%$ Class A pan evaporation (Ep) to natural precipitation, along a $20-\mathrm{m}$ turf area. Evaluation during the summers of 1993-96 indicated that grasses differed in drought resistance and persistence under variable irrigation regimes. Irrigation (Ep) required to maintain acceptable turf quality for respective grasses was 'Rebel II' $(67 \%)$, 'Meyer' $(68 \%)$, 'Nortam' $(44 \%)$, 'Tifway' (35\%), and 'Prairie' (26\%). Higher dollar spot (Sclerotinia homoeocarpa Bennett) infection was observed at $115 \%$ Ep irrigation regime in 'Tifway' bermudagrass, whereas gray leaf spot [Pyricularia grisea (Hebert) Barr] was observed only at $10 \%$ Ep irrigation regime in St. Augustinegrass plots. An outbreak of brown patch (Rhizoctonia solani Kuehn.) occurred in Sept. 1996 in St. Augustinegrass plots receiving irrigation at $>80 \% \mathrm{Ep}$.
\end{abstract}

Drought is a common environmental stress causing the decline and loss of turfgrass. In most areas of the United States, irrigation is required to maintain desirable turfgrass quality throughout the growing season. As water conservation has become an important issue, researchers have put significant effort into developing and evaluating turf species that have good drought resistance (Aronson et al., 1987; Carrow, 1995, 1996a; Fry and Butler, 1989; Gibeault et al., 1985; Kim and Beard, 1988; Qian et al., 1997). The results of these studies clearly indicate that turfgrasses differ in their performance during drought events. However, considerable variability in rankings of relative drought resistance has been reported. A greenhouse study with selected grasses indicated that relative drought resistance based on leaf firing was bermudagrass $=$ zoysiagrass $=$ buffalograss $>$ tall fescue $>$ St. Augustinegrass (Sifers et al., 1990). A field study in Georgia ranked grasses for drought resistance in the

Received for publication on 5 Oct. 1998. Accepted for publication on 19Jan. 1999. We thank S. Wilhelm, Dr. M. Rogoyski, and D. Christensen for review assistance. The cost of publishing this paper was defrayed in part by the payment of page charges. Under postal regulations, this paper therefore must be hereby marked advertisement solely to indicate this fact order of 'Tifway' bermudagrass > 'Raleigh' St. Augustinegrass > 'Rebel II' tall fescue $\geq$ 'Meyer' zoysiagrass (Carrow, 1996a). In Kansas, the relative drought resistance of four turfgrasses was 'Prairie' buffalograss > 'Midlawn' bermudagrass = 'Mustang tall fescue' > 'Meyer' zoysiagrass (Qian et al., 1997). Carrow (1996a) suggested that variations in the rankings of drought resistance may relate to regional climatic conditions, assessment method, and duration of drought events.

Bermudagrass, St. Augustinegrass, and tall fescue are the most commonly used turfgrass species in northern Texas. The use of buffalograss and zoysiagrass has increased during recent years because of their low maintenance requirements. To select drought-resistant and water-saving grasses, and to provide better irrigation management recommendations, additional long-term field evaluation is needed.

Even though water is considered to be the most precious and limited resource, there are many situations where excess water is applied without regard to plant needs. In addition to increasing the potential for leaching and surface runoff of pesticides and fertilizers, excessive irrigation may also cause detrimental effects, such as making the turf more prone to pest attacks (Colbaugh and Elmore, 1985).
Compared with the information regarding drought stress, little is known about the response of turfgrass to excessive irrigation. More information is needed on how each species performs under various irrigation regimes.

The linear gradient irrigation system (LGIS), as described by Hanks et al. (1976), generates uniform irrigation gradients and allows determination of turfgrass drought resistance and water requirements in situ (White et al., 1993). It further facilitates the evaluation of turf persistence under continuous moisture gradients. This study was undertaken using LGIS on five major turfgrasses in northern Texas to: 1) determine the minimum irrigation requirements and relative drought resistance; and 2) evaluate the long-term effects of irrigation levels on turf persistence, weed invasion, and disease incidence.

\section{Materials and Methods}

Experimental design. The experiment was conducted at the Texas A\&M Univ.-Dallas Research Center on a Houston clay soil (veryfine, montmorillonitic, thermic Typic Chromuderts). An underground linear gradient irrigation system (LGIS) was installed in 1992. The LGIS consists of a single row of inground irrigation heads (rotor pop-up sprinklers, gear drive, Thompson Manufacturer, Chino, Calif.) located in the middle of the study area, spaced $6 \mathrm{~m}$ apart, which is about one-third of the maximum throw of each head. This sprinkler arrangement is designed to generate a perpendicular irrigation gradient, i.e., decreasing irrigation volumes with increasing distance from the irrigation line source (Hanks et al., 1976).

Four warm-season grasses ('Tifway' bermudagrass, 'Nortam' St. Augustinegrass, 'Prairie' buffalograss, and 'Meyer' zoysiagrass) and one cool-season grass ('Rebel II' tall fescue) were solid-sodded in July 1992 into four $7 \times 20$-m plots perpendicular to the center irrigation line, creating a randomized complete-block design with four replications. During establishment, all grasses were uniformly watered.

From May 1993 to Nov. 1996, irrigation was applied every $3 \mathrm{~d}$ at a rate of $120 \%$ of the previous 3-d Class A pan evaporation (Ep) to the area immediately adjacent to the central irrigation line. The $120 \%$ Ep kept the soil nearest the line source near field capacity (Horst et al., 1989; White et al., 1993), whereas the portion of the plot farthest from the center line received no supplemental irrigation. Irrigation was applied from 1700 to $1900 \mathrm{HR}$; efforts were made to irrigate only when wind was minimal, but this was not always possible. The reference Class A pan, which was used to determine the volume of irrigation, was located $\approx 100$ m east of the experimental area, where it was supported $15 \mathrm{~cm}$ aboveground by a wooden pallet.

Buffalograss, St. Augustinegrass, and tall fescue were mowed weekly at $5.1 \mathrm{~cm}$, whereas bermudagrass and zoysiagrass were mowed at $2.5 \mathrm{~cm}$; all clippings were removed. Nitrogen was applied at rates and times based on the 
growing seasons and requirements of each of the grasses. Bermudagrass and St. Augustinegrass received an annual application of $\mathrm{N}$ at $245 \mathrm{~kg} \cdot \mathrm{ha}^{-1}$, whereas buffalograss and zoysiagrass received $148 \mathrm{~kg} \cdot \mathrm{ha}^{-1}$, applied between May and August. Tall fescue received N in February, March, May, September, and November for an annual rate of 245 $\mathrm{kg} \cdot \mathrm{ha}^{-1}$. Since one of our objectives was to assess the irrigation effects on disease and weed incidence, no herbicides or fungicides were applied throughout the study.

Water distribution and minimum water requirements. Water distribution was determined at least monthly by using rain gauges positioned at $1.5-\mathrm{m}$ increments from the irrigation line source. Periodic adjustments were made to ensure that the desired water distribution was maintained. Data on irrigation output along the gradient were converted to an equivalent of percent Ep. A least squares, nonlinear regression of irrigation level vs. distance from the line source was used to predict irrigation distribution along the gradient (Fig. 1). Despite efforts to water only when wind was minimal, the water distribution curve was still skewed slightly to the western side of the LGIS.

To assess the minimum water requirements and relative drought resistance of the selected turfgrasses, the distance between the central irrigation line and the position at which the turf could not maintain acceptable quality due to drought stress was determined during summer drought periods. By substituting the value of distance in the regression equation of water distribution (Fig. 1), we calculated the minimum water requirement as a proportion of the Class A pan evaporation (\% Ep) for each turfgrass on each evaluation date.

Turf performance under three irrigation levels. Within each plot, three $2 \times 7-\mathrm{m}$ subplots (located 1.0, 8.0, and $14.0 \mathrm{~m}$ from the central irrigation line) were selected along the irrigation gradient to represent three irrigation regimes (high, medium, and low). The amount of water received by these three subplots was about equal to $115 \%, 55 \%$, and $10 \% \mathrm{Ep}$.

Turf performance, including turf quality, density, turf ground coverage, spring greenup, disease incidence, and weed invasion, was evaluated at these three locations along the gradient. Turf quality was evaluated monthly during the growing seasons on a 1 to 9 scale, where 6 was the minimum acceptable turf quality and 9 was the best. Turf density was likewise rated on a 1 to 9 scale, where 9 was the best. Turf ground coverage was rated as percentage of area covered by living turf; turf ground coverage at the end of the study was considered to be an indicator of turf persistence. Weed invasion was rated as percent area covered with weeds. Disease incidence was determined by counting the number of diseased lesions or patches.

Weather permitting, clippings were harvested twice a month during the growing season from a $1.7-\mathrm{m}^{2}$ area at each of the three irrigation levels. Clippings were dried at $80^{\circ} \mathrm{C}$ for $24 \mathrm{~h}$ prior to weighing.

Data analysis. Analysis of variance

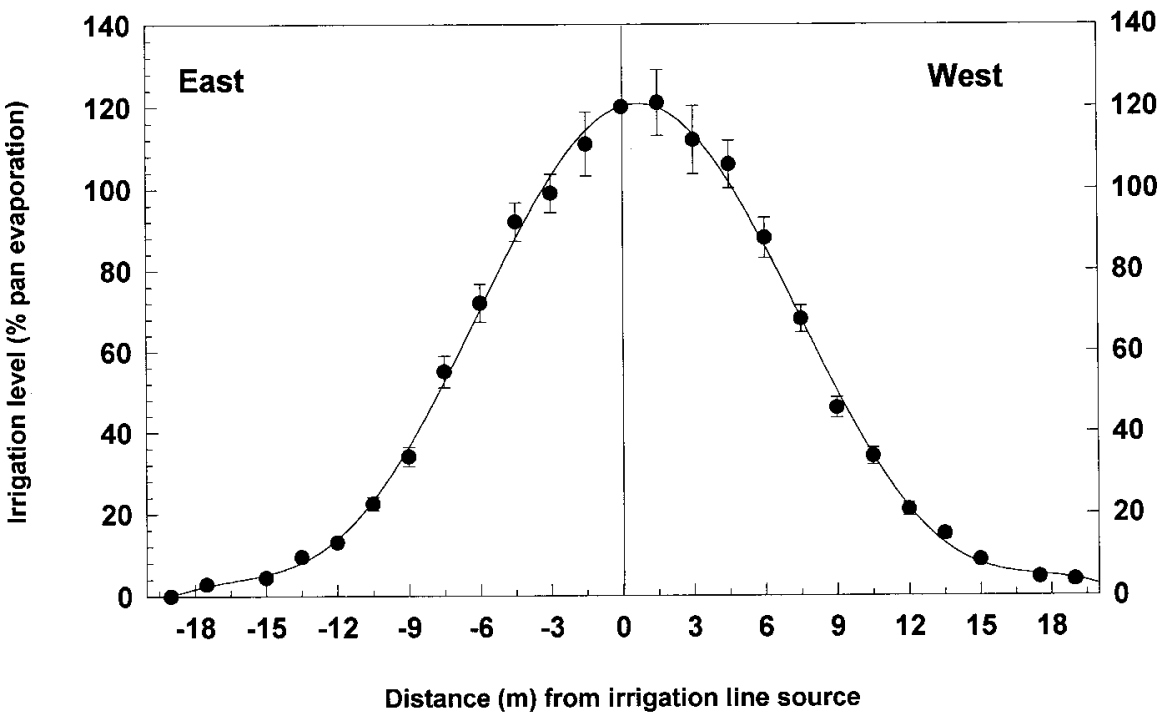

Fig. 1. Irrigation distribution of the linear gradient irrigation system. Bars represent standard errors. Fitted equation: $\% \mathrm{Ep}=120+1.87 \mathrm{X}-1.37 \mathrm{X}^{2}-0.017 \mathrm{X}^{3}+6.21 \mathrm{E}-03 \mathrm{X}^{4}+5.65 \mathrm{E}-05 \mathrm{X}^{5}-1.25 \mathrm{E}-05 \mathrm{X}^{6}-5.86 \mathrm{E}-$ $08 \mathrm{X}^{7}+9.36 \mathrm{E}-09 \mathrm{X}^{8} \cdot R^{2}=0.99$.

Table 1. Irrigation requirements [\% pan evaporation (Ep)] of five turfgrasses under a linear gradient irrigation system.

\begin{tabular}{lrrcccrr}
\hline \hline & \multicolumn{7}{c}{ Date } \\
\cline { 2 - 6 } Grass & 6 Jul. 93 & 4 Aug. 94 & 7 Sept. 95 & 8 Aug. 96 & 7 Nov. 96 & Range \\
\hline 'Tifway' bermudagrass & $21.4 \mathrm{~b}^{\mathrm{z}}$ & $11.9 \mathrm{~b}$ & $20.1 \mathrm{a}$ & $35.0 \mathrm{~b}$ & $31.7 \mathrm{ab}$ & $12-35$ \\
'Prairie' buffalograss & $6.5 \mathrm{a}$ & $6.5 \mathrm{a}$ & $24.3 \mathrm{a}$ & $26.6 \mathrm{a}$ & $22.8 \mathrm{a}$ & $7-26$ \\
'Nortam' St. Augustinegrass & $43.5 \mathrm{c}$ & $12.3 \mathrm{~b}$ & $26.6 \mathrm{a}$ & $38.0 \mathrm{~b}$ & $32.6 \mathrm{ab}$ & $12-44$ \\
'Meyer' zoysiagrass & $67.5 \mathrm{~d}$ & $64.0 \mathrm{c}$ & $38.5 \mathrm{ab}$ & $52.0 \mathrm{c}$ & $45.7 \mathrm{~b}$ & $39-68$ \\
'Rebel II' tall fescue & $66.5 \mathrm{~d}$ & $65.0 \mathrm{c}$ & $52.3 \mathrm{~b}$ & $61.0 \mathrm{~d}$ & $49.0 \mathrm{~b}$ & $49-67$ \\
\hline
\end{tabular}

${ }^{\mathrm{z}}$ Mean separation within columns by Fisher's LSD test, $P \leq 0.05$.

(ANOVA) was used to test the effects of turfgrass species, irrigation regime, and their interaction (SAS Institute, 1989). A singlefactor ANOVA was used for data on minimum irrigation requirements because the irrigation level was not an explanatory variable. All hypotheses were tested at $P \leq 0.05$. Percentage data (e.g., percent turf groundcover, percent weed invasion) were first arcsin transformed to satisfy the normality assumption of ANOVA. When $\mathrm{F}$ values were significant, means were separated using a least significant difference (LSD) test at $P \leq 0.05$.

\section{Results and Discussion}

Minimum water requirements and relative drought resistance. Operation of the LGIS began in May 1993. Significant effects of irrigation on turfgrass wilting appeared in July, indicating that stress gradients had been established.

Analysis of the minimum irrigation required to maintain acceptable quality revealed that there were significant main effects for turfgrass species and evaluation date, as well as a species $\times$ date interaction. Therefore, the minimum irrigation requirement for each species on each evaluation date is presented (Table 1).

Minimum irrigation requirements to prevent drought stress were: 'Rebel II' tall fescue, $49 \%$ to $67 \%$ Ep; 'Meyer' zoysiagrass, $39 \%$ to
$68 \%$ Ep; 'Nortam' St. Augustinegrass, $12 \%$ to $44 \%$ Ep; 'Tifway' bermudagrass, $12 \%$ to $35 \%$ Ep; and 'Prairie' buffalograss, $7 \%$ to $26 \%$ Ep (Table 1). A range of water requirements is given for each grass because the amount of water required to prevent drought stress varied with the date of evaluation, suggesting that the amount of water needed to maintain acceptable turf quality was affected by weather conditions, the duration of drought events, and the length of growing seasons. However, to be sure that acceptable turf quality is maintained throughout the growing season, the amounts of water equivalent to the upper end of the range for each turfgrass should be applied.

Meyer and Gibeault (1986) reported that the water requirements ranged from $43 \%$ to $63 \%$ Ep for warm-season and $49 \%$ to $83 \%$ Ep for cool-season turfgrasses in California. In Georgia, Carrow (1995) reported that the average water requirements from May through October were $66 \%, 80 \%, 76 \%$, and $78 \%$ Ep for 'Tifway' bermudagrass, 'Meyer' zoysiagrass, 'Raleigh' St. Augustinegrass, and 'Rebel II' tall fescue, respectively. Our values for water requirements are lower than those reported for the same species in California and Georgia. This may have been because: 1) the minimum water requirements to maintain turf quality were reported in our study, 2) turfgrasses in our study were maintained under low-maintenance conditions, and the expectation for ac- 
Table 2. Mean visual quality, density, and clipping yields of five turfgrasses under a linear gradient irrigation system during growing season (1994-96).

\begin{tabular}{|c|c|c|c|c|c|c|c|c|c|c|}
\hline \multirow[b]{2}{*}{ Grass } & \multirow[b]{2}{*}{$\%$ Ep: } & \multicolumn{3}{|c|}{ Turf quality $^{z}$} & \multicolumn{3}{|c|}{ Turf density $^{z}$} & \multicolumn{3}{|c|}{ Clipping yield $\left(\mathrm{g} \cdot \mathrm{m}^{-2} \cdot \mathrm{d}^{-1}\right)^{\mathrm{y}}$} \\
\hline & & 115 & 55 & $<10$ & 115 & 55 & $<10$ & 115 & 55 & $<10$ \\
\hline 'Tifway' bermudagrass & & $7.6 \mathrm{Aa}^{x}$ & $7.3 \mathrm{Aa}$ & $5.2 \mathrm{Bb}$ & $8.3 \mathrm{Aa}$ & $8.0 \mathrm{Aa}$ & $5.0 \mathrm{Bb}$ & $2.97 \mathrm{Ab}$ & $2.55 \mathrm{Ab}$ & $1.57 \mathrm{Bb}$ \\
\hline 'Prairie' buffalograss & & $5.1 \mathrm{Cc}$ & $6.9 \mathrm{Aab}$ & $5.7 \mathrm{Ba}$ & $4.2 \mathrm{Cd}$ & $7.2 \mathrm{Aab}$ & $6.3 \mathrm{Ba}$ & $1.77 \mathrm{Bc}$ & $2.91 \mathrm{Ab}$ & $2.19 \mathrm{Ba}$ \\
\hline 'Nortam' St. Augustinegrass & & $6.0 \mathrm{Bb}$ & $6.6 \mathrm{Aab}$ & $4.4 \mathrm{Cc}$ & $6.1 \mathrm{Ac}$ & $6.0 \mathrm{Ab}$ & $3.5 \mathrm{Bc}$ & $4.44 \mathrm{Aa}$ & $3.91 \mathrm{Aa}$ & $1.43 \mathrm{Bb}$ \\
\hline 'Meyer' zoysiagrass & & $7.7 \mathrm{Aa}$ & $6.3 \mathrm{Bb}$ & $3.4 \mathrm{Cd}$ & $8.4 \mathrm{Aa}$ & $6.8 \mathrm{Bab}$ & $2.0 \mathrm{Cd}$ & $1.91 \mathrm{Ac}$ & $1.75 \mathrm{Ac}$ & --- \\
\hline 'Rebel II' tall fescue & & $6.7 \mathrm{Ab}$ & $6.0 \mathrm{Ab}$ & $4.0 \mathrm{Bd}$ & $7.4 \mathrm{Ab}$ & $5.9 \mathrm{Bb}$ & $2.1 \mathrm{Cd}$ & $2.47 \mathrm{Ab}$ & $2.10 \mathrm{Abc}$ & $0.50 \mathrm{Bc}$ \\
\hline
\end{tabular}

${ }^{\mathrm{z}}$ Means of monthly ratings from May to October from 1993 to 1996 . Turf quality and density were rated on scales of 1 to 9 , where 6 is the minimum acceptable quality and 9 is the optimal.

yean of 16 dates from 1994 to 1996.

${ }^{x}$ Mean separation within parameters by LSD. Uppercase letters indicate mean separation among irrigation regimes for a given turfgrass species; lowercase letters indicate mean separation among turfgrass species within columns ( irrigation regimes).

ceptable turf quality may have been lower than those previously reported.

The minimum irrigation requirements indicated that, under the conditions of this study, the ranking for relative drought resistance was 'Prairie' buffalograss > 'Tifway' bermudagrass $\geq$ 'Nortam' St. Augustinegrass > 'Meyer' zoysiagrass = 'Rebel II' tall fescue. This ranking generally agreed with the findings of Carrow (1996a). In contrast to a Kansas study in which deep-rooted 'Mustang' tall fescue exhibited better drought resistance than shallow-rooted 'Meyer' zoysiagrass (Qian et al., 1997), 'Rebel II' tall fescue, a relatively deeprooted tall fescue cultivar (Carrow, 1996b), performed equal to or slightly worse than 'Meyer' zoysiagrass in this study. The higher summer temperature in Texas and the clay soil in our study site probably negated tall fescue's resistance to drought. We observed intermediate drought resistance for St. Augustinegrass. However, Sifers et al. (1990) reported that bermudagrass, zoysiagrass, and buffalograss were more drought tolerant than tall fescue, and tall fescue was more tolerant than $\mathrm{St}$. Augustinegrass. Their research was conducted in soil-filled containers that may have limited potential root development. Rooting ability is one of the most important components of drought resistance in turfgrass (Huang et al., 1997; Qian et al., 1997).

Turf performance under three irrigation levels. Turf quality differed among irrigation regimes for each grass (Table 2). Even though quality of bermudagrass, zoysiagrass, and tall fescue increased linearly as irrigation increased, quality was not improved for bermudagrass, buffalograss, and St. Augustinegrass when watered at a rate $>55 \%$ Ep. Except for 'Prairie' buffalograss, all grasses had lower turf quality when irrigated at $10 \%$ Ep compared with areas irrigated at $55 \%$ or $115 \%$ Ep. 'Prairie' buffalograss had the lowest quality rating at $115 \%$ Ep.

Tall fescue and zoysiagrass had denser turf canopies at $115 \%$ Ep than other irrigation levels (Table 2). In contrast, buffalograss lost acceptable turf density at $115 \%$ Ep, but exhibited acceptable turf density in areas receiving $55 \%$ and $10 \%$ Ep.Zoysiagrass, tall fescue, and St. Augustinegrass had very low density in areas receiving $10 \% \mathrm{Ep}$.

With the exception of buffalograss, dry weights of turf clippings increased with increasing irrigation (Table 2). Weed encroachment in the zoysiagrass plot receiving $10 \% \mathrm{Ep}$ prevented clipping collection. However, buffalograss yielded more clippings at $55 \%$ Ep than at $115 \%$ Ep. This result once again showed that buffalograss performed poorly under high irrigation conditions.

Irrigation level also significantly affected spring green-up (data not shown). Earlier spring green-up was noted at $115 \%$ Ep for bermudagrass and zoysiagrass, at 55\% Ep for tall fescue and St. Augustinegrass, and at 10\% Ep for buffalograss. Irrigation at $115 \%$ Ep delayed spring green-up in buffalograss.

'Tifway' bermudagrass had a relatively wide range of adaptation, and exhibited decreased turf groundcover only at $<18 \%$ Ep after 4 years of irrigation.

'Prairie' buffalograss produced $>90 \%$ turf coverage at $10 \%$ and $55 \%$ Ep, but covered only $56 \%$ of the area receiving $115 \%$ Ep. Annual bluegrass (Poa annua L.), bermudagrass, St. Augustinegrass, dallisgrass (Paspalum dilatatum Poir) encroachment into buffalograss was significantly enhanced at $115 \% \mathrm{Ep}$, suggesting that it had better persistence at low than at high irrigation regimes.

'Meyer' zoysiagrass had the highest ground coverage at $115 \%$ Ep and exhibited excellent persistence and superior performance in areas receiving $>68 \% \mathrm{Ep}$, but deteriorated when subjected to $<39 \%$ Ep. Ground coverage was only $11 \%$ following irrigation with $10 \% \mathrm{Ep}$ for 3 years. Prostrate spurge (Chamaesyce humistrata Engelm) and spotted knapweed (Centaurea maculosa Lam.) severely invaded zoysiagrass plots irrigated at $<39 \%$ Ep.

Tall fescue and St. Augustinegrass had a relatively narrow range of adaptation. The drought stress caused severe thinning of tall fescue and St. Augustinegrass at deficit irrigation regimes. Disease pressure observed in Aug. and Sept. 1996 in areas irrigated at $>80 \%$ Ep had significantly reduced St. Augustinegrass coverage in Nov. 1996, when the experiment was terminated. Tall fescue plots irrigated with $>100 \%$ Ep exhibited a high percentage of invasion by Texas bluegrass (Poa arachnifera Torr.), Kentucky bluegrass (Poa pratensis L.), and annual bluegrass. Due to the compatibility of Poa with tall fescue, the turf quality and density of tall fescue were maintained at the high irrigation regime.

During the experimental period in 1996 , brown patch and gray leaf spot in St. Augustinegrass, dollar spot in bermudagrass, and leaf spot in tall fescue were observed. No diseases were detected in 'Meyer' zoysiagrass or 'Prairie' buffalograss. Dollar spot incidence was greater in 'Tifway' bermudagrass plots watered at $>80 \%$ pan evaporation. Our results support the findings of Jiang et al. (1998), who reported that excessive irrigation enhanced dollar spot. In Aug. and Sept. 1996, gray leaf spot was greatly enhanced in St. Augustinegrass watered at $10 \%$ Ep. On 3 Sept. 1996, an outbreak of brown patch symptoms was observed in St. Augustinegrass irrigated with $>80 \%$ Ep. Microscopic examination indicated that Rhizoctonia solani Kuehn. was the causal agent. Colbaugh and Elmore (1985) inferred that continuously moist environments favored Rhizoctonia brown patch. In Maryland, brown patch injury was greater in perennial ryegrass when irrigated in the evening than when watered in the morning. In our study, excessive irrigation applied between 1700 and $1900 \mathrm{HR}$, plus a low percolation rate $\left(\approx 0.5 \mathrm{~cm} \cdot \mathrm{h}^{-1}\right)$ of the clay soil, resulted in a favorable environment for Rhizoctonia brown patch. However, brown patch symptoms were only observed in St. Augustinegrass when irrigated with $>80 \%$ Ep.

In conclusion, among the five grasses tested, 'Prairie' buffalograss had the best drought tolerance, followed by 'Tifway' bermudagrass and 'Nortam' St. Augustinegrass in northern Texas. 'Meyer' zoysiagrass and 'Rebel II' tall fescue had the highest irrigation requirements. Buffalograss failed to maintain persistence at $115 \%$ Ep, whereas zoysiagrass, tall fescue, and St. Augustinegrass lost turf coverage at $10 \%$ Ep.

\section{Literature Cited}

Aronson, L.J., A.J. Gold, and R.J. Hull. 1987. Coolseason turfgrass response to drought stress. Crop Sci. 27:1261-1266.

Carrow, R.N. 1995. Drought resistance aspects of turfgrasses in the southeast: ET and crop coefficients. Crop Sci. 35:1685-1690.

Carrow, R.N. 1996a. Drought resistance aspects of turfgrasses in the southeast: Root-shoot responses. Crop Sci. 36:687-694.

Carrow, R.N. 1996b. Drought avoidance characteristics of diverse tall fescue cultivars. Crop Sci. 36:371-377.

Colbaugh, P.F. and C.L. Elmore. 1985. Influence of water on pest activity, p. 113-129. In: V.A. Gibeault and S.T. Cockerham (eds.). Turfgrass water conservation. Coop. Ext. Publ. 21405, Univ. of California, Riverside.

Fry, J.D. and J.D. Butler. 1989. Responses of tall and hard fescue to deficit irrigation. Crop Sci. 29:1536-1541.

Gibeault, V.A., J.L. Meyer, V.B. Youngner, and S.T. Cockerham. 1985. Irrigation of turfgrass 
below replacement of evapotranspiration as a means of water conservation: Performance of commonly used turf-grasses, p. 347-356. In: Proc. Fifth Intl. Turfgrass Res. Conf.

Hanks, R.J., J. Keller, V.P. Rasmussen, and G.D. Wilson. 1976. Line source sprinkler for continuous variable irrigation crop production studies. Soil Sci. Soc. Amer. Proc. 40:426-429.

Horst, G.L., J.C. O'Toole, and K.L. Faver. 1989. Seasonal and species variation in baseline functions for determining crop water stress indices in turfgrass. Crop Sci. 29:1227-1232.

Huang, B., R.R. Duncan, and R.N. Carrow. 1997. Drought-resistance mechanisms of seven warm- season turfgrasses under surface soil drying: II. Root aspects. Crop Sci. 37:1863-1869.

Jiang, H., J.D. Fry, and N. Tisserat. 1998. Assessing irrigation management for its effects on disease and weed levels in perennial ryegrass. Crop Sci. $38: 440-445$.

Kim, K.S. and J.B. Beard. 1988. Comparative turfgrass evapotranspiration rates and associated plant morphological characteristics. Crop Sci. 28:328-331.

Meyer, J.L. and V.A. Gibeault. 1986. Turfgrass performance under reduced irrigation. Calif. Agr. 40:19-20.

Qian, Y.L., J.D. Fry, and W. Upham. 1997. Rooting and drought avoidance of four turfgrasses in Kansas. Crop Sci. 37:905-910.

SAS Institute. 1989. SAS/STAT user's guide. vers. 6, 4th ed. SAS Inst., Cary, N.C.

Sifers, S.I., J.B. Beard, and M.H. Hall. 1990. Comparative dehydration avoidance and drought resistance among major warm-season turfgrass species and cultivars. Texas Turfgrass Research1990. PR-4738-4768. Texas Agr. Expt. Sta. Publ., College Station.

White, R.H., M.C. Engelke, S.J. Morton, and B.A. Ruemmele. 1993. Irrigation water requirement of zoysiagrass. Intl. Turfgrass Soc. Res. J. 7:587593. 